GRASAS Y ACEITES 66 (4)

October-December 2015, e103

ISSN-L: 0017-3495

doi: http://dx.doi.org/10.3989/gya.0245151

\title{
Evaluation of the therapeutic effect of Nigella sativa crude oil and its blend with omega-3 fatty acid-rich oils in a modified hepatorenal syndrome model in rats
}

\author{
S.Y. Al-Okbi ${ }^{a}$, D.A. Mohamed ${ }^{\text {a }}$, T.E. Hamed ${ }^{\mathrm{a}}$ and A.E. Edris ${ }^{\mathrm{b}, \varpi}$ \\ ${ }^{a}$ Department of Food Sciences and Nutrition, National Research Centre, Dokki, Cairo, Egypt \\ ${ }^{b}$ Aroma and Flavor Chemistry Department, National Research Centre, Dokki, Cairo, Egypt \\ Corresponding author: amr_edris@hotmail.com
}

Submitted: 12 February 2015; Accepted: 10 June 2015

\begin{abstract}
SUMMARY: In the present study, the hepato and reno-protective effect of Nigella sativa crude oil and its binary blend with omega-3 fatty acid-rich oils (fish and flaxseed oils) was studied in a modified hepatorenal syndrome model (MHRS) in rats. MHRS was induced through feeding a high fructose diet followed by an intraperitoneal injection of galactosamine hydrochloride. Nigella oil and its different blends were given as a daily oral dose to MHRS rats. Two control groups of MHRS and normal healthy rats were run. Different biochemical and nutritional parameters were assessed. The induction of MHRS produced liver and kidney dysfunction, and elevated oxidative stress, an inflammatory biomarker, endothelin 1, and plasma cholesterol. Reduced plasma high density lipoprotein cholesterol, albumin and $\mathrm{Ca}$ and elevated urinary $\mathrm{N}$-acetyl- $\beta$-D-Glucosaminidase and liver fats were noticed. The administration of Nigella crude oil that originally had $0.2 \%$ total omega-3 fatty acids or its blend with fish oil (17.9\% omega-3) or flaxseed oil (42.1\% omega-3) significantly improved all biochemical parameters of MHRS. There was no significant difference in the biochemical parameters among the different oil treated groups regardless of the omega- 3 fatty acid content. This may point out to the potential profound effect of the volatile oil fraction of Nigella crude oil which may compensates for its low omega-3 content.
\end{abstract}

KEYWORDS: Hepatorenal syndrome; Nigella crude oil; Oil blends; Omega-3 fatty acids

RESUMEN: Evaluación del efecto terapéutico del aceite crudo de Nigella sativa y su mezcla con aceites ricos en ácidos grasos omega-3 en un modelo de síndrome hepatorenal modificado en ratas. En el presente estudio, el efecto hepato- y reno-protector de aceites crudos de Nigella sativa y su mezcla binaria con aceites ricos en ácidos grasos omega-3 (pescado y aceites de linaza) fue estudiado en un modelo modificado de síndrome hepatorenal (MHRS) en ratas. MHRS fue inducido a través de la alimentación de una dieta alta en fructosa seguido de la inyección intraperitoneal de clorhidrato de galactosamina. Diferentes aceites fueron suministrados como dosis oral diaria a ratas con MHRS. Se realizaron dos grupos de control de MHRS y ratas sanas normales. Se evaluaron diferentes parámetros bioquímicos y nutricionales. La inducción de la MHRS produce disfunción hepática y renal, elevado estrés oxidativo y biomarcadores inflamatorios, endotelina 1, y colesterol en plasma. Se observó una reducción del colesterol plasmatico de lipoproteínas de alta densidad, albúmina y Ca, elevación en orina de $\mathrm{N}$-acetil- $\beta$-D-glucosaminidasa y de la grasa del hígado. La administración de aceite crudo de Nigella que tiene un $0,2 \%$ de ácidos grasos omega-3 totales o su mezcla con aceite de pescado $(17,9 \%$ de omega- 3 ) o aceite de linaza (42,1\% de omega-3) mejoró significativamente todos los parámetros bioquímicos de MHRS. No hubo diferencia significativa en los parámetros bioquímicos entre los diferentes grupos tratados con los aceites ensayados independientemente del contenido de ácidos grasos omega-3. Con esto se puede resaltar el potencial efecto de la fracción volátil del aceite crudo de Nigella. 
PALABRAS CLAVE: Aceite crudo Nigella; Ácidos grasos omega-3; Mezcla de aceites; Síndrome hepatorenal

Citation/Cómo citar este artículo: Al-Okbi SY, Mohamed DA, Hamed TE, Edris AE. 2015. Evaluation of the therapeutic effect of Nigella sativa crude oil and its blend with omega-3 fatty acid-rich oils in a modified hepatorenal syndrome model in rats. Grasas Aceites 66 (4): e103. doi: http://dx.doi.org/10.3989/gya.0245151.

Copyright: (C) 2015 CSIC. This is an open-access article distributed under the terms of the Creative Commons Attribution-Non Commercial (by-nc) Spain 3.0 Licence.

\section{INTRODUCTION}

Chronic liver disease causes significant morbidity and mortality because of the number of complications associated with this disease. This can comprise hepatic encephalopathy, ascites and hepatorenal syndrome. Hepatorenal syndrome (HRS) is defined as renal failure caused by acute or chronic liver failure without any histological reasons (Bataller et al., 1998). Two categories of HRS are described: Type 1 (HRS) is considered to be a specific complication of advanced cirrhosis characterized by a rapidly progressive decrease in kidney function. It is defined as a $100 \%$ increase in serum creatinine to a final value $>2.5 \mathrm{mg} \cdot \mathrm{dL}^{-1}$ in less than two weeks in humans. Type 2 HRS occurs in the setting of refractory ascites with a steady, moderate degree of functional renal failure (Arroyo et al., 1996). Considering the management of HRS, patients with type 1 HRS usually require hospitalization, whereas those with type 2 HRS can be treated as outpatients.

HRS is still one of a few great secrets of today's medicine. The Pathomechanism of this syndrome is still poorly understood. Therefore, the pathogenesis of renal function alteration associated with liver disease remains to be elucidated. The exact etiology of HRS is unknown, although vasodilatation in the splanchnic area is suggested to be the basic pathophysiological reason for this disease (Demirbas et al., 2012). Vasodilatation can develop as a result of cirrhosis, portal hypertension, reflex systemic and splanchnic vasoconstriction. On the other hand, some factors were suggested to be the causes of type 1 HRS including sepsis, variceal hemorrhage, shock, severe acute alcoholic hepatitis, or use of nephrotoxics (Muñoz, 2008). The decrease in renal perfusion and also in the glomerular filtration rate, sodium retention and deterioration of excretion of free water are the major renal problems which remain progressive according to the stage of liver disease (Demirbas et al., 2012). Therefore, a new approach for future studies of the pathology in cirrhotic patients with renal dysfunction is required. Based on the ignorance of the exact mechanism of HRS, therapy for such a syndrome has not yet been established, where symptomatic treatment is only adopted which is not a radical remedy. Symptomatic treatments include vasoconstrictor therapy, in order to reverse splanchnic vasodilation, together with albumin. This treatment was found to be effective in about $50 \%$ of patients with type 1 HRS and improves survival (Fagundes and Ginè, 2012). These symptomatic treatments could reduce the risk of developing type 2 HRS (Planas et al., 2006). Another treatment like renal vasodilators (Snowdon et al., 2013) is also an option for managing HRS. However, liver transplantation is considered the preferred treatment because it offers a cure for both liver and renal dysfunction (Wadei et al., 2006). Different reviews are available disclosing different aspects of this disease and more detailed strategies for treatment (Mohindra and Kumar, 2013; Davenport et al., 2012).

In Egypt and in many other developing countries there is a continuous increase in the percentage of patients with liver and kidney dysfunction. This motivated the research team of the current investigation to study the interrelation between both diseases represented by HRS and how to protect, overcome or manage through the oral administration of some natural nutraceutical oils from plant and marine sources. Experimental animal models could be utilized in order to explain the patho-physiological state, and the mechanisms involved in the etiology of HRS as well as studying new efficient therapy. So, in the present research galactosamine hydrochloride was used to induce HRS in Sprague dawley rats according to Saracyn et al. (2012). In our previous work, (Al-Okbi et al., 2013) it was revealed that the crude oil of Nigella sativa had a promising protection from steatohepatitis, which is a fatty liver with inflammation in rats.

In a continuation of that trend, the present study was dedicated to study the protective effect of Nigella sativa crude oil and its mixture with other omega-3 fatty acid-rich oils like flaxseed or fish oil toward the induced modified hepatorenal syndrome (MHRS). MHRS was induced in rats via feeding a high fructose diet with a simultaneous intraperitoneal injection of galactosamine hydrochloride to induce steatohepatitis and HRS. Another objective of the current study was to shed light on the biochemical changes and biomarkers that may be related to MHRS.

\section{MATERIALS AND METHODS}

\subsection{Materials}

Mature dried seeds of black cumin (Nigella sativa $\mathrm{L}$, family Ranunculaceae) and flaxseeds (Linum usitatissimum L, family Linaceae) were purchased from a specialized local herbal store located in Cairo, Egypt. 
The seeds were authenticated by Dr. Tereez Labib, a consultant of Plant Taxonomy, Ministry of Agriculture, Egypt. A voucher specimen from each plant seed was deposited in the National Research Centre Herbarium, Egypt. Fish oil (a mixture of anchovy cod, mackerel and sardine oils) was obtained from an Egyptian local market in soft gelatin capsules under the trade name "Natrol Omega-3 Fish oil". This dietary supplement is manufactured by Natrol. Inc. Chatsworth, CA 91311 USA. D-(+)-galactosamine hydrochloride was obtained from the Sigma-Aldrich Chemical Co. (St. Louis, MO, USA). All other chemicals used in the experiment were of analytical grade and used as is without further purification.

\subsection{Animals}

Male Sprague Dawley rats weighing 120.0-165.0 g (mean \pm SD of 141.2 \pm 12.2 ) were used in the present study. The animals were obtained from the Animal House of National Research Centre, Cairo, Egypt. The animals were kept individually in stainless steel metabolic cages; water and food were given ad-libtium.

\subsection{Diets}

Experimental diets were prepared as in Table 1. A salt mixture and vitamin mixtures were prepared according to previous methods (Briggs and Williams, 1963; Morcos, 1976). Oil soluble vitamins were given orally in a dose of $0.1 \mathrm{~mL} / \mathrm{rat} / \mathrm{week}$. Two types of diets were prepared; a balanced and a high fructose diet as described by Kawasaki et al. (2009) and Al-Okbi et al. (2013).

\subsection{Extraction of Nigella and flaxseed crude oils.}

Nigella sativa seeds and flaxseeds were crushed twice using a grinder model (MF10 microfine grinder drives). The crushed samples were pressed separately with a laboratory type Carver hydraulic press under $10.000 \mathrm{lb} /$ inch pressure at room temperature

TABle 1. Composition of different diets (g per $100 \mathrm{~g}$ ).

\begin{tabular}{lcc}
\hline Ingredients & High fructose diet (HFD) & Balanced diet \\
\hline Casein & 17 & 12 \\
Corn oil & - & 10 \\
Butter fat & 5.5 & - \\
Fructose & 70 & - \\
Starch & - & 47 \\
Sucrose & - & 23.5 \\
Salt mix. & 3.5 & 3.5 \\
Vitamin mix. & 1 & 1 \\
Cellulose & 3 & 3 \\
\hline
\end{tabular}

according to Üstun et al., 1990. The produced oil was filtered and kept in dark bottles under deep freezing conditions until use.

\subsection{Blending of Nigella crude oil with flaxseed and fish oils}

A certain weight of Nigella crude oil was mixed separately with an equal weight of either flaxseed oil or fish oil with continuous stirring for 5 minutes to ensure homogeneity. These binary oil blends (Nigellal flaxseed and Nigella/fish at 1:1 weight ratios) were left for $1 \mathrm{~h}$ to equilibrate at room temperature before formulation into water-based emulsion for oral administration.

\subsection{Formulation of Nigella crude oil and its binary blends in water-based emulsion for oral administration}

Nigella crude oil and its binary blends with flaxseed and fish oils were mixed separately with Tween 80 as a non-ionic surfactant at $10.0 \%$ of the oils' weight (e.g. $1.0 \mathrm{~g}$ surfactant for each $10.0 \mathrm{~g}$ oil or oil blend). The oil-surfactant mixtures were vortexed for $1 \mathrm{~min}$ then left for $1 \mathrm{~h}$ to equilibrate before a drop-wise addition of the oils to a calculated amount of distilled water. This oral administration system is called a selfemulsifying delivery system which forms oil-in-water emulsion spontaneously upon titration in water.

\subsection{Preparation and analysis of the fatty acid composition of Nigella crude oil and its binary blends}

The oils were transformed into their corresponding volatile fatty acid methyl esters via a transesterification process using 3.0\% methanol/sulfuric acid according to A.O.A.C. (2000). Two microliters of the prepared fatty acid methyl esters were injected (at a split ratio 10:1) into a Hewlett Packard HP 6890 gas chromatograph equipped with a flame ionization detector. A $30 \mathrm{~m} \times 0.32 \mathrm{~mm}$ i.d. fused silica capillary column coated with DB-5 was used to separate the different methyl esters. The oven temperature was programmed from $150{ }^{\circ} \mathrm{C}$ to $240{ }^{\circ} \mathrm{C}$ at a rate of $2.5^{\circ} \mathrm{C} \cdot \mathrm{min}^{-1}$ with a $30 \mathrm{~min}$ hold at the final temperature. The injector and detector temperatures were $230^{\circ} \mathrm{C}$ and $250^{\circ} \mathrm{C}$, respectively. Helium was used as a carrier gas at a flow rate of $1.0 \mathrm{~mL} \cdot \mathrm{min}^{-1}$. Methyl esters were identified by comparing their retention times with the available authentic standards (Sigma-Aldrich, St. Louis USA). Values of area $\%$ were the means of two injections from two different extractions \pm SD.

A gas chromatographic-mass spectroscopic (GC-MS) analysis was also conducted for the full identification of fatty acid methyl esters. A HewlettPackard 5972 GC-MS system was equipped with the 
same column and conditions used as in GC analysis. The ionization voltage was $70 \mathrm{eV}$ and the ion source temperature was $170^{\circ} \mathrm{C}$.

The full identities of the fatty acid methyl esters were revealed and verified by automatic matching of their mass fragmentation patterns $(\mathrm{m} / \mathrm{z})$ with that of standard components stored in the electronic mass spectral library (NIST: National Institute of Standards and Technology) that was built in to the GC-MS software.

\subsection{Extraction and analysis of Nigella volatile oil}

Nigella volatile oil was extracted from the crude oil via the hydro-distillation method using a Clevengertype apparatus (European Pharmacopoeia, 1996). A certain weight of the crude oil was mixed with distilled water at 1:5 weight/volume ratios and distilled for $3 \mathrm{~h}$. The weight of the obtained volatile oil was determined and correlated to the weight of the crude oil to give the yield percent. The value of the yield percent was an average of two extractions \pm SD. A chemical analysis of the volatile oil was conducted using gas chromatography in order to estimate the percentage of thymoquinone and p-cymene which are the most prominent and biologically active components of the volatile oil. Twenty microliters of the volatile oil were diluted in $1.0 \mathrm{~mL}$ diethyl ether and $2.0 \mu \mathrm{L}$ of this mixture were injected at a 10:1 split ratio into a Hewlett Packard HP 6890 gas chromatograph equipped with a flame ionization detector. A $30 \mathrm{~m} \times 0.32 \mathrm{~mm}$ i.d. fused silica capillary column coated with DB-5 was used to separate the volatile oil components. The oven temperature was programmed from $50{ }^{\circ} \mathrm{C}$ to $220^{\circ} \mathrm{C}$ at a rate of $3^{\circ} \mathrm{C} \cdot \mathrm{min}^{-1}$. The injector and detector temperatures were $230{ }^{\circ} \mathrm{C}$ and $250{ }^{\circ} \mathrm{C}$, respectively. Helium was used as a carrier gas at a flow rate of $1.0 \mathrm{~mL} \cdot \mathrm{min}^{-1}$. Thymoquinone and p-cymene were identified by comparing their retention times with authentic standards (Sigma-Aldrich, St. Louis USA). Values of the area $\%$ of these two components were the means of two injections from two different extractions \pm SD.

\subsection{Biological experiment}

Thirty rats were divided into five groups, each comprised of six rats. The first was the normal control group where rats received a balanced diet without any treatments. The rats of the second group were fed a high fructose diet for the induction of steatohepatitis (Kawasaki et al., 2009). The rats of groups 3, 4 and 5 were fed a high fructose diet and given a daily oral dose of $265 \mathrm{mg} \cdot \mathrm{kg}^{-1}$ rat body weight of $N$. sativa crude oil, a mixture of $N$. sativa crude oil and fish oil (1:1) and a mixture of $N$. sativa crude oil and flaxseed oil (1:1), respectively by stomach tube. The dose of $265 \mathrm{mg} \cdot \mathrm{kg}^{-1}$ was used because N. sativa crude oil was reported previously to improve fatty liver at this dose level (Al-Okbi et al., 2013). On the $34^{\text {th }}$ day all rats except the normal healthy control (group: 1) were given $1.1 \mathrm{~g} \cdot \mathrm{kg}^{-1}$ body weight of galactosamine hydrochloride via intraperitoneal injection as a $200 \mathrm{mg} \cdot \mathrm{mL}^{-1}$ solution in saline to induce hepatorenal syndrome (Saracyn et al., 2012). Therefore, according to the last treatment, group 2 served as a control with both steatohepatitis and hepatorenal syndrome (MHRS) while groups 3-5 are test groups with MHRS and treated with different oils. During the experiment, body weight and food intake were recorded weekly. At the end of the study, the total food intake, body weight gain and food efficiency ratio (Body weight gain/total food intake) were calculated. The whole experimental period was thirtyfive days.

Urine samples were collected twenty-four hours after the galactosamine hydrochloride injection for the determination of $\mathrm{N}$-acetyl- $\beta$-D-Glucosaminidase (NAG) (Price and Whiting, 1992). Creatinine was determined in the collected 24h urine (Houot, 1985) for the calculation of creatinine clearance. Blood samples were collected from the fasting rats 24 hours after the galactosamine injection. An aliquot of blood was used for the determination of hemoglobin (Hb) (VanKampen and Zijlstra, 1965). Another aliquot was placed in heparinized tubes and centrifuged for the separation of plasma. Plasma total cholesterol (T-Ch) (Watson, 1960), high density lipoprotein cholesterol (HDL-Ch) (Burstein et al., 1970), low density lipoprotein cholesterol (LDL-Ch) (Schriewer et al., 1984) and triglycerides (TG) (Megraw et al., 1979) were determined. The HDL-Ch/T-Ch ratio was calculated. Plasma malondialdehyde (MDA) (Satoh, 1978) and total antioxidant capacity (TAC) (Koracevic et al., 2001) were determined as indicators of lipid peroxidation and antioxidant state, respectively. The plasma tumor necrosis factor- $\alpha$ $(\mathrm{TNF}-\alpha)$ (an inflammatory biomarker) (Stepaniak et al., 1995) was assessed. The activity of aspartate transaminase (AST) and alanine transaminase (ALT) (Reitman and Frankel, 1957), plasma albumin (Doumas et al., 1972) and total and direct bilirubin (Gambino, 1965) were determined as indicators of liver function. Plasma creatinine (Houot, 1985) and urea (Fawcett and Scott, 1960) were assessed as indicators of kidney function. Plasma endothelin 1 (ET-1) (Zhou et al., 2002) was determined as an expected biomarker of the hepatorenal syndrome. Livers and kidneys were immediately removed and weighed. The livers were stored at $-20^{\circ} \mathrm{C}$ until analysis. Hepatic lipids were extracted and weighed as described by Folch et al. (1957) and Cequier-Sánchez et al. (2008). Triglyceride and cholesterol contents in the liver were measured according to Megraw et al. (1979) and Watson, (1960), respectively. The animal experiments were carried out according to the Medical Research Ethics Committee, National Research Centre; Cairo, Egypt. 


\subsection{Statistical analysis}

The results of animal experiments were expressed as the mean $\pm \mathrm{SE}$ and they were analyzed statistically using the one-way analysis of variance ANOVA followed by Duncan's test. In all cases $p<0.05$ was used as the criterion for statistical significance.

\section{RESULTS}

The fatty acid composition of Nigella crude oil and its binary blend with flaxseed and fish oils is shown in Table 2. From the table it is evident that Nigella crude oil is poor in omega-3 fatty acids $(0.2 \%)$ however, it is rich in omega-6 (60.4\%) and omega-9 $(25.2 \%)$ fatty acids. Blending Nigella crude oil with either fish or flaxseed oil improved the total omega- 3 content of the mixture to reach $17.9 \%$ and $42.1 \%$ of the total fatty acids, respectively. This provides omega- 6 to omega- 3 ratios of 1.88 and 0.73 for Nigella/fish and Nigella/flaxseed oil blends, respectively.

Table 3 shows the fatty acid composition of the pure individual flaxseed and fish oils that were used to blend with Nigella crude oil. The table confirmed the fact that these oils are rich sources of omega-3 fatty acids which reached $42.7 \%$ and $57.9 \%$ for both fish and flaxseed oils, respectively.
The extraction of the volatile oil from Nigella crude oil revealed that this fraction constitutes $2.6 \% \pm 0.3$ of the crude oil's weight. The gas chromatographic analysis revealed that thymoquinone $(68.1 \pm 0.8 \%)$ and p-cymene $(20.1 \pm 0.4 \%)$ are the major constituents of the volatile oil fraction.

Table 4 shows the liver and kidney functions of the different experimental groups. The plasma levels of the total and direct bilirubin and the plasma activities of AST and ALT were increased significantly in the control rats with MHRS indicating liver dysfunction. Also plasma albumin was reduced significantly in the MHRS rats compared with the normal control rats. The plasma levels of creatinine, urea and endotheline-1 (ET-1) increased significantly in the MHRS control rats compared with the normal control rats, indicating kidney dysfunction. The oral administration of Nigella crude oil, Nigellal fish or Nigella/flaxseed oils (which encompass the three test groups) showed significant improvement in liver and kidney functions with different degrees compared with the MHRS control group. On the other hand, plasma urea and creatinine were completely normalized on oral administration of different oils where they matched that of the normal control rats. When comparing the test groups with each other, there were no significant changes in the parameters indicating liver and kidney functions

TABLE 2. Fatty acids composition of Nigella, Nigella/fish and Nigella/flaxseed oils blended at 1:1 weight ratio

\begin{tabular}{|c|c|c|c|c|c|}
\hline \multirow[b]{2}{*}{ Fatty acid carbon No. } & \multirow[b]{2}{*}{ Common name } & \multirow[b]{2}{*}{ CAS Name } & \multicolumn{3}{|c|}{ Average area $(\%)$} \\
\hline & & & Nigella & Nigellalfish & Nigellalflaxseed \\
\hline C14:0 & Myristic & Tetradecanoic & $0.1 \pm 0.07$ & $2.0 \pm 0.4$ & $<0.1$ \\
\hline $\mathrm{C} 16: 4$ & - & $6,9,12,15$-Hexadecatetraenoic & nd & $0.7 \pm 0.01$ & nd \\
\hline $\mathrm{C} 16: 3(\mathrm{n}-3)$ & Roughanic & 7,10,13-Hexadecatrienoic & nd & $0.6 \pm 0.01$ & nd \\
\hline $\mathrm{C} 16: 1(\mathrm{n}-7)$ & Palmitoleic & 9-Hexadecenoic & $0.1 \pm 0.07$ & $4.2 \pm 0.2$ & $<0.1$ \\
\hline $\mathrm{C} 16: 0$ & Palmitic & Hexadecanoic & $9.5 \pm 0.5$ & $11.5 \pm 0.5$ & $11.4 \pm 0.07$ \\
\hline $\mathrm{C} 18: 2(\mathrm{n}-6)$ & Linoleic & 9,12-Octadienoic & $60.4 \pm 3.6$ & $32.8 \pm 1.6$ & $30.9 \pm 0.7$ \\
\hline C18:3 (n3) & $\alpha$-linolenic & $9,12,15$-Octadecatrienoic & $0.2 \pm 0.07$ & $0.2 \pm 0.05$ & $42.1 \pm 0.6$ \\
\hline C18:1 (n-9) & Oleic & 9-Octadecenoic & $21.9 \pm 2.6$ & $21.7 \pm 1.0$ & $11.7 \pm 0.1$ \\
\hline $\mathrm{C} 18: 1(\mathrm{n}-7)$ & vaccenic & 11-Octadecenoic & $1.0 \pm 0.07$ & $2.8 \pm 0.1$ & $<0.1$ \\
\hline $\mathrm{C} 18: 0$ & Stearic & Octadecanoic & $3.3 \pm 0.2$ & $3.5 \pm 0.3$ & $3.1 \pm 0.1$ \\
\hline $\mathrm{C} 20: 4(\mathrm{n}-6)$ & Arachidonic & Eicosa-5,8,11,14-tetraenoic & nd & $0.9 \pm 0.01$ & nd \\
\hline$C 20: 5(n-3)$ & Timnodonic & Eicosa-5,8,11,14,17-pentaenoic & nd & $10.2 \pm 0.6$ & nd \\
\hline $\mathrm{C} 20: 4(\mathrm{n}-3)$ & Eicosatetraenoic & Eicosa-8,11,14,17-tetraenoic & nd & $0.7 \pm 0.01$ & nd \\
\hline $\mathrm{C} 20: 1(\mathrm{n}-9)$ & Eicosenoic & 11-Eicosenoic & $3.3 \pm 0.2$ & $3.1 \pm 0.04$ & $1.2 \pm 0.1$ \\
\hline$C 22: 6(n-3)$ & Cervonic acid & Docosa-4,7,10,13,16,19-hexaenoic & nd & $5.2 \pm 0.5$ & nd \\
\hline $\mathrm{C} 22: 5(\mathrm{n}-3)$ & Clupanodonic & Docosa-7,10,13,16,19-pentaenoic & nd & $1.0 \pm 0.2$ & nd \\
\hline Total n-9 & & & $25.2 \%$ & $24.8 \%$ & $12.9 \%$ \\
\hline Total n-6 & & & $60.4 \%$ & $33.7 \%$ & $30.9 \%$ \\
\hline Total n-3 & & & $0.2 \%$ & $17.9 \%$ & $42.1 \%$ \\
\hline Ratio n-6/n-3 & & & 302 & 1.88 & 0.73 \\
\hline
\end{tabular}

nd: not detected. 
TABLE 3. Fatty acid composition of the pure fish and flaxseed oils.

\begin{tabular}{|c|c|c|c|c|}
\hline \multirow{3}{*}{$\begin{array}{l}\text { Fatty acid carbon No. } \\
\text { C14:0 }\end{array}$} & \multirow{3}{*}{$\begin{array}{l}\text { Common name } \\
\text { Myristic }\end{array}$} & \multirow{3}{*}{$\begin{array}{r}\text { CAS Name } \\
\text { Tetradecanoic }\end{array}$} & \multirow{2}{*}{\multicolumn{2}{|c|}{$\begin{array}{c}\text { Average area (\%) } \\
\text { Fish oil Flaxseed oil }\end{array}$}} \\
\hline & & & & \\
\hline & & & $4.82 \pm 0.2$ & nd \\
\hline $\mathrm{C} 16: 4$ & - & $6,9,12,15$-Hexadecatetraenoic & $1.72 \pm 0.01$ & nd \\
\hline $\mathrm{C} 16: 3(\mathrm{n}-3)$ & Roughanic & 7,10,13-Hexadecatrienoic & $1.28 \pm 0.01$ & nd \\
\hline $\mathrm{C} 16: 1(\mathrm{n}-7)$ & Palmitoleic & 9-Hexadecenoic & $8.45 \pm 0.1$ & nd \\
\hline $\mathrm{C} 16: 0$ & Palmitic & Hexadecanoic & $13.44 \pm 0.3$ & $7.0 \pm 0.1$ \\
\hline C18:4 (n3) & Stearidonic & $6,9,12,15$-Octadecatetraenoic & $3.20 \pm 0.1$ & nd \\
\hline $\mathrm{C} 18: 2(\mathrm{n}-6)$ & Linoleic & 9,12-Octadienoic & $1.57 \pm 0.01$ & $12.4 \pm 0.2$ \\
\hline C18:1 (n-9) & Oleic & 9-Octadecenoic & $10.85 \pm 0.2$ & $16.8 \pm 1.5$ \\
\hline $\mathrm{C} 18: 3(\mathrm{n}-3)$ & $\alpha$-linolenic & $9,12,15$-Octadecatrienoic & $0.44 \pm 0.01$ & $57.9 \pm 2.4$ \\
\hline $\mathrm{C} 18: 1(\mathrm{n}-7)$ & vaccenic & 11-Octadecenoic & $3.90 \pm 0.1$ & nd \\
\hline $\mathrm{C} 18: 0$ & Stearic & Octadecanoic & $3.64 \pm 0.1$ & $4.5 \pm 0.2$ \\
\hline $\mathrm{C} 20: 4(\mathrm{n}-6)$ & Arachidonic & Eicosa-5,8,11,14-tetraenoic & $1.17 \pm 0.01$ & nd \\
\hline $\mathrm{C} 20: 5(\mathrm{n}-3)$ & Timnodonic & Eicosa-5,8,11,14,17-pentaenoic & $20.15 \pm 1.8$ & nd \\
\hline $\mathrm{C} 20: 4(\mathrm{n}-3)$ & Eicosatetraenoic & Eicosa-8,11,14,17-tetraenoic & $1.37 \pm 0.01$ & nd \\
\hline C20:1 (n-9) & Eicosenoic & 11-Eicosenoic & $1.73 \pm 1.03$ & nd \\
\hline $\mathrm{C} 22: 6(\mathrm{n}-3)$ & Cervonic acid & Docosa-4,7,10,13,16,19-hexaenoic & $13.77 \pm 0.4$ & nd \\
\hline $\mathrm{C} 22: 5(\mathrm{n}-3)$ & Clupanodonic & Docosa-7,10,13,16,19-pentaenoic & $2.51 \pm 0.1$ & nd \\
\hline Total n-9 & & & $12.5 \%$ & $16.8 \%$ \\
\hline Total n-6 & & & $2.7 \%$ & $12.4 \%$ \\
\hline Total n-3 & & & $42.7 \%$ & $57.9 \%$ \\
\hline
\end{tabular}

nd: not detected.

TABLE 4. Liver and kidney functions of different experimental groups*

\begin{tabular}{|c|c|c|c|c|c|}
\hline Plasma Parameters & Normal control & $\begin{array}{l}\text { MHRS } \\
\text { control }\end{array}$ & Nigella oil & $\begin{array}{l}\text { Nigella oil \& } \\
\text { Fish oil (1:1) }\end{array}$ & $\begin{array}{c}\text { Nigella oil \& } \\
\text { Flaxseed oil (1:1) }\end{array}$ \\
\hline Creatinine $\left(\mathrm{mg} \cdot \mathrm{dL}^{-1}\right)$ & $0.686^{\mathrm{a}} \pm 0.04$ & $1.04^{\mathrm{b}} \pm 0.1$ & $0.761^{\mathrm{a}} \pm 0.03$ & $0.744^{\mathrm{a}} \pm 0.04$ & $0.806^{\mathrm{a}} \pm 0.03$ \\
\hline Urea $\left(\mathrm{mg} \cdot \mathrm{dL}^{-1}\right)$ & $30.3^{\mathrm{a}} \pm 1.1$ & $44.3^{\mathrm{b}} \pm 2.8$ & $30.3^{\mathrm{a}} \pm 0.5$ & $30.2^{\mathrm{a}} \pm 0.2$ & $30.1^{\mathrm{a}} \pm 0.7$ \\
\hline Albumin $\left(\mathrm{g} \cdot \mathrm{dL}^{-1}\right)$ & $4.2^{\mathrm{a}} \pm 0.2$ & $2.65^{\mathrm{b}} \pm 0.1$ & $3.1^{\mathrm{c}} \pm 0.1$ & $3.2^{\mathrm{c}} \pm 0.1$ & $3.2^{\mathrm{c}} \pm 0.1$ \\
\hline $\operatorname{ALT}(\mathrm{U} / \mathrm{l})$ & $55.8^{\mathrm{a}} \pm 1.2$ & $86.2^{\mathrm{b}} \pm 1.9$ & $76.7^{\mathrm{c}} \pm 2.2$ & $74^{\mathrm{c}} \pm 1.8$ & $72.7^{\mathrm{c}} \pm 1.4$ \\
\hline $\operatorname{AST}(\mathrm{U} / \mathrm{l})$ & $40.8^{\mathrm{a}} \pm 0.8$ & $80.5^{\mathrm{b}} \pm 1.4$ & $70.2^{c} \pm 2.6$ & $67.5^{\mathrm{c}} \pm 2.1$ & $66.7^{\mathrm{c}} \pm 1.7$ \\
\hline T. Bilirubin $\left(\mathrm{mg} \cdot \mathrm{dL}^{-1}\right)$ & $0.356^{\mathrm{a}} \pm 0.01$ & $0.497^{\mathrm{b}} \pm 0.01$ & $0.411^{\mathrm{c}} \pm 0.01$ & $0.395^{\mathrm{c}} \pm 0.01$ & $0.383^{\mathrm{c}} \pm 0.02$ \\
\hline D. Bilirubin $\left(\mathrm{mg} \cdot \mathrm{dL}^{-1}\right)$ & $0.157^{\mathrm{a}} \pm 0.004$ & $0.242^{\mathrm{b}} \pm 0.01$ & $0.18^{\mathrm{c}} \pm 0.01$ & $0.167^{\mathrm{c}} \pm 0.01$ & $0.162^{\mathrm{c}} \pm 0.01$ \\
\hline ET-1 $\left(\mathrm{ng} \cdot \mathrm{mL}^{-1}\right)$ & $22.0^{\mathrm{a}} \pm 1.3$ & $39.7^{\mathrm{b}} \pm 2.8$ & $27.2^{\mathrm{c}} \pm 1.7$ & $26.3^{\mathrm{c}} \pm 2.4$ & $27.7^{\mathrm{c}} \pm 1.1$ \\
\hline
\end{tabular}

*Mean \pm S.E.

In the same row, values having the same letter are insignificantly different and values having different letters are significantly different at the level $\mathrm{p}<0.05$.

reflecting an equal effect of the different oils in improving such parameters.

Table 5 shows the plasma and liver lipid profile of the different experimental groups. MHRS control rats exhibited a significant increase in plasma total cholesterol, triglycerides, LDL-Ch and the ratio of $\mathrm{T}-\mathrm{Ch} / \mathrm{HDL}-\mathrm{Ch}$ compared with the normal control rats. In addition, significant increases were observed in total fat, T-Ch and TG in the liver tissue of the MHRS control rats compared to the normal control group.
The rats of the test groups showed a significant improvement in plasma lipid profile, T-Ch/HDL-Ch and the contents of total liver fat, T-Ch and TG with different degrees.

Table 6 shows the blood hemoglobin, total antioxidant capacity, malondialdehyde and tumor necrosis factor-alpha of the different experimental groups. Blood hemoglobin and total plasma antioxidants were reduced significantly in the MHRS control rats compared with the normal control group. The oral administrations of different oils elevated 
TABLE 5. Plasma and liver lipid profile of different experimental groups*

\begin{tabular}{lrrrrr}
\hline Parameters & Normal control & MHRS control & Nigella oil & $\begin{array}{c}\text { Nigella oil \& } \\
\text { fish oil }\end{array}$ & $\begin{array}{c}\text { Nigella oil \& } \\
\text { flaxseed oil }\end{array}$ \\
\hline Plasma & & & & & \\
T-Cholesterol $\left(\mathrm{mg} \cdot \mathrm{dL}^{-1}\right)$ & $82.8^{\mathrm{a}} \pm 3.0$ & $112.1^{\mathrm{b}} \pm 2.8$ & $92.4^{\mathrm{c}} \pm 2.4$ & $91.5^{\mathrm{c}} \pm 1.8$ & $92.5^{\mathrm{c}} \pm 1.1$ \\
Triglycerides $\left(\mathrm{mg} \cdot \mathrm{dL}^{-1}\right)$ & $83.1^{\mathrm{a}} \pm 2.7$ & $162.4^{\mathrm{b}} \pm 2.4$ & $130.3^{\mathrm{c}} \pm 4.0$ & $128.7^{\mathrm{c}} \pm 2.5$ & $129.5^{\mathrm{c}} \pm 1.6$ \\
HDL-Ch $\left(\mathrm{mg} \cdot \mathrm{dL}^{-1}\right)$ & $31.8^{\mathrm{a}} \pm 1.2$ & $21.8^{\mathrm{b}} \pm 0.6$ & $28.7^{\mathrm{c}} \pm 0.7$ & $30.5^{\mathrm{c}} \pm 1.1$ & $30.7^{\mathrm{c}} \pm 0.9$ \\
LDL-Ch $\left(\mathrm{mg} \cdot \mathrm{dL}^{-1}\right)$ & $22.3^{\mathrm{a}} \pm 0.4$ & $81.5^{\mathrm{b}} \pm 2.1$ & $55.5^{\mathrm{c}} \pm 2.9$ & $52.3^{\mathrm{c}} \pm 2.4$ & $53.3^{\mathrm{c}} \pm 2.3$ \\
T-Ch/ HDL-Ch & $2.6^{\mathrm{a}} \pm 0.1$ & $5.2^{\mathrm{b}} \pm 0.2$ & $3.2^{\mathrm{c}} \pm 0.1$ & $3.0^{\mathrm{c}} \pm 0.1$ & $3.0^{\mathrm{c}} \pm 0.1$ \\
Tissue & & & & & \\
Liver total fat (mg $\cdot \mathrm{g}^{-1}$ tissue) & $23.2^{\mathrm{a}} \pm 0.3$ & $44.2^{\mathrm{b}} \pm 1.2$ & $32^{\mathrm{c}} \pm 0.7$ & $30.5^{\mathrm{c}} \pm 0.7$ & $30.8^{\mathrm{c}} \pm 0.4$ \\
Liver T-Cholesterol (mg/g tissue) & $2.2^{\mathrm{a}} \pm 0.2$ & $7.1^{\mathrm{b}} \pm 0.2$ & $5.2^{\mathrm{c}} \pm 0.1$ & $4.9^{\mathrm{c}} \pm 0.05$ & $5.1^{\mathrm{c}} \pm 0.1$ \\
Liver Triglycerides $\left(\mathrm{mg} \cdot \mathrm{g}^{-1}\right.$ tissue) & $5.3^{\mathrm{a}} \pm 0.1$ & $13.95^{\mathrm{b}} \pm 0.5$ & $8.4^{\mathrm{c}} \pm 0.2$ & $8^{\mathrm{c}} \pm 0.2$ & $8.2^{\mathrm{c}} \pm 0.2$ \\
\hline
\end{tabular}

*Mean \pm S.E.

In the same row, values having the same letter are insignificantly different and values having different letters are significantly different at level $\mathrm{p}<0.05$.

TABLE 6. Hemoglobin, total antioxidant capacity, malondialdehyde and tumor necrosis factor-alpha of different experimental groups*

\begin{tabular}{lccccc}
\hline Parameters & Normal control & MHRS control & Nigella oil & $\begin{array}{c}\text { Nigella oil \& } \\
\text { Fish oil }\end{array}$ & $\begin{array}{c}\text { Nigella oil \& } \\
\text { Flaxseed oil }\end{array}$ \\
\hline $\mathrm{Hb}\left(\mathrm{g} \cdot \mathrm{dL}^{-1}\right)$ & $13.3^{\mathrm{a}} \pm 0.543$ & $9.9^{\mathrm{b}} \pm 0.467$ & $11.8^{\mathrm{c}} \pm 0.718$ & $12.1^{\mathrm{c}} \pm 0.774$ & $12.6^{\mathrm{c}} \pm 0.581$ \\
$\mathrm{TAC}\left(\mathrm{mm} \cdot \mathrm{L}^{-1}\right)$ & $1.57^{\mathrm{a}} \pm 0.038$ & $0.872^{\mathrm{b}} \pm 0.036$ & $1.21^{\mathrm{c}} \pm 0.058$ & $1.28^{\mathrm{c}} \pm 0.070$ & $1.3^{\mathrm{c}} \pm 0.058$ \\
$\mathrm{MDA}\left(\mathrm{nmol} \cdot \mathrm{mL}^{-1}\right)$ & $5.5^{\mathrm{a}} \pm 0.217$ & $23.1^{\mathrm{b}} \pm 0.634$ & $15.7^{\mathrm{c}} \pm 0.685$ & $14.2^{\mathrm{c}} \pm 0.958$ & $14.8^{\mathrm{c} \pm 0.777}$ \\
$\mathrm{TNF}-\alpha\left(\mathrm{pg} \cdot \mathrm{mL}^{-1}\right)$ & $19.7^{\mathrm{a}} \pm 0.604$ & $31.7^{\mathrm{b}} \pm 0.735$ & $15.1^{\mathrm{c}} \pm 0.506$ & $14.1^{\mathrm{c}} \pm 0.774$ & $14.7^{\mathrm{c} \pm 0.882}$ \\
\hline
\end{tabular}

*Mean \pm S.E.

In the same row, values having the same letter are insignificantly different and values having different letters are significantly different at the level $\mathrm{p}<0.05$.

blood hemoglobin and plasma TAC levels to different degrees. The plasma levels of MDA and TNF- $\alpha$ increased significantly in the MHRS control rats compared with the normal control group. The MHRS rats administered different oils showed a significant reduction in MDA levels and TNF- $\alpha$. Blood hemoglobin, plasma total antioxidant capacity and plasma malondialdehyde levels of the test groups were still not matching that of the normal control group.

Table 7 shows that creatinine clearance was reduced significantly in the MHRS control group compared to normal control rats. The administration of different oils showed a significant increase in creatinine clearance compared with the MHRS control group.

The urine level of NAG (Table 5) was elevated significantly in the MHRS group compared to the normal control rats. The administration of different oils showed a significant reduction in NAG compared with the MHRS control group.

Table 8 shows the non-significant changes when all nutritional parameters, liver weight/body weight $\%$ and kidney weight/body weight $\%$ of the MHRS control rats were compared with the normal control
TABLE 7. Creatinine clearance and NAG of different experimental groups*

\begin{tabular}{lcl}
\hline Groups & $\begin{array}{c}\text { Creatinine } \\
\text { clearance }(\mathbf{m l} / \mathbf{m i n})\end{array}$ & $\begin{array}{c}\text { NAG } \\
\text { (IU/l) }\end{array}$ \\
\hline Normal control & $0.945^{\mathrm{a}} \pm 0.05$ & $38.1^{\mathrm{a}} \pm 0.66$ \\
MHRS & $0.501^{\mathrm{b}} \pm 0.07$ & $46.1^{\mathrm{b}} \pm 1.8$ \\
Nigella sativa oil & $0.636^{\mathrm{c}} \pm 0.05$ & $36.9^{\mathrm{c}} \pm 2.5$ \\
Nigella sativa oil \& fish oil & $0.686^{\mathrm{c}} \pm 0.06$ & $35.2^{\mathrm{c}} \pm 1.7$ \\
Nigella sativa oil \& Flaxseed oil & $0.705^{\mathrm{c}} \pm 0.04$ & $37.0^{\mathrm{c}} \pm 1.3$ \\
\hline
\end{tabular}

*Mean \pm SE.

In the same column, values having the same letter are insignificantly different and values having different letters are significantly different at level $\mathrm{p}<0.05$.

rats. The oral administration of different oils showed non-significant changes in all the aforementioned parameters except for the rats given the oral administration of Nigella sativa crude oil which showed a significant reduction in final body weight, body weight gain and food efficiency ratio in comparison to all the conducted groups. 
TABLE 8. Nutritional parameters of different experimental groups*

\begin{tabular}{lccccc}
\hline Parameters & Normal control & MHRS control & Nigella oil & $\begin{array}{c}\text { Nigella oil } \\
\text { \& fish oil }\end{array}$ & $\begin{array}{c}\text { Nigella oil \& } \\
\text { flaxseed oil }\end{array}$ \\
\hline Initial BW(g) & $141.3^{\mathrm{a}} \pm 6.2$ & $141^{\mathrm{a}} \pm 6.8$ & $141.2^{\mathrm{a}} \pm 6.69$ & $141.3^{\mathrm{a}} \pm 2.4$ & $141^{\mathrm{a}} \pm 3.2$ \\
Final BW (g) & $225^{\mathrm{a}} \pm 6.8$ & $228.2^{\mathrm{a}} \pm 4.7$ & $207.3^{\mathrm{b}} \pm 7.1$ & $227.8^{\mathrm{a}} \pm 7.6$ & $228.2^{\mathrm{a}} \pm 4.2$ \\
Body weight gain $(\mathrm{g})$ & $83.7^{\mathrm{a}} \pm 2.01$ & $87.2^{\mathrm{a}} \pm 3.7$ & $66.2^{\mathrm{b}} \pm 2.8$ & $86.5^{\mathrm{a}} \pm 5.8$ & $87.2^{\mathrm{a}} \pm 5.5$ \\
Total Food intake (g) & $512.8^{\mathrm{a}} \pm 8.1$ & $518.8^{\mathrm{a}} \pm 4.2$ & $508.5^{\mathrm{a}} \pm 2.3$ & $510.3^{\mathrm{a}} \pm 6.9$ & $514.8^{\mathrm{a}} \pm 7.8$ \\
Food efficiency ratio & $0.163^{\mathrm{a}} \pm 0.01$ & $0.168^{\mathrm{a}} \pm 0.07$ & $0.130^{\mathrm{b}} \pm 0.05$ & $0.169^{\mathrm{a}} \pm 0.09$ & $0.169^{\mathrm{a}} \pm 0.01$ \\
Liver weight/body weight $\%$ & $2.6^{\mathrm{a}} \pm 0.1$ & $2.7^{\mathrm{a}} \pm 0.2$ & $2.9^{\mathrm{a}} \pm 0.3$ & $2.8^{\mathrm{a}} \pm 0.2$ & $2.8^{\mathrm{a}} \pm 0.2$ \\
Kidney weight/body weight $\%$ & $0.699^{\mathrm{a}} \pm 0.02$ & $0.74^{\mathrm{a}} \pm 0.01$ & $0.896^{\mathrm{a}} \pm 0.05$ & $0.805^{\mathrm{a}} \pm 0.05$ & $0.843^{\mathrm{a}} \pm 0.04$ \\
\hline
\end{tabular}

*Mean \pm S.E.

In the same row, values having the same letter are insignificantly different and values having different letters are significantly different at level $\mathrm{p}<0.05$.

\section{DISCUSSION}

In the present study it was decided to induce steatohepatitis before the induction of HRS with the aim of enhancing the induction of HRS on intraperitoneal injection with galactosamine hydrochloride. MHRS in the current study referred to the blend of steatohepatitis and HRS. It was also the interest of the authors in the present study to assess the biochemical and nutritional changes that occur during MHRS in a trial to study the mechanism of action and patho-physiology of the hepatorenal syndrome.

From the obtained results, this model was found to be satisfactory for studying the therapeutic potential of the investigated oils against HRS, because both renal and hepatic dysfunction occurred on intraperitoneal injection of galactosamine hydrochloride.

The increased plasma creatinine and reduced creatinine clearance in MHRS in the present study reflected that glomerular function, proximal tubules and glomerular filtration rate are affected in HRS as reported previously (Van Lente and Sult, 1989; Skálová, 2005). Renal dysfunction in patients with cirrhosis with superimposed inflammation was reported previously to be associated with significant tubular injury (Shah et al., 2013). This model also showed elevated oxidative stress in the present study, represented by the increased MDA and the reduced total antioxidant which might be a biomarker of tissue destruction and inflammation in both kidney and liver. In the MHRS model, an elevated inflammatory biomarker (tumor necrosis factor-alpha) was also noticed in the current results. The inhibition of oxidative stress and simultaneous inflammatory biomarker, were reported to prevent the development of renal failure in an animal model of HRS (Saracyn, et al., 2008). Therefore, a natural anti-inflammatory and antioxidant might have therapeutic potential towards HRS.

ET-1 showed a significant elevation in the MHRS model in the present study, which supports the previous proposal of being a biomarker of HRS (Anand et al., 2002) due to the increased endothelin (A) of the renal cortex which is important in the pathogenesis of renal failure that occurs in patients with acute liver failure or HRS. Urinary NAG was significantly elevated in the MHRS model in the present study reflecting tubular dysfunction and kidney parenchymal damage as reported by Skálová (2005). In agreement with this result, high urinary NAG was reported in infants with liver cirrhosis (Aydogdu et al., 2004) pointing to an occurrence of renal dysfunction and HRS. The plasma albumin level was reduced significantly in MHRS rats in the present study which confirms the work of García-Martínez et al. (2013), who showed that not only albumin concentration but also albumin function is reduced in liver failure.

Hemoglobin reduction was noticed in MHRS in rats, pointing to some sorts of anemia. Anemia is prevalent in chronic kidney disease which could be due to erythropoietin deficiency, inhibition of erythropoiesis by uremic solutes, and reduction in red blood cell life span. Other possible causes include iron, B12 or folic acid deficiency or blood loss. Dysfunction of the endogenous erythropoietin is usually clinically evident once the glomerular filtration rate falls below $20.0-25.0 \mathrm{~mL} \cdot \mathrm{min}^{-1}$ in humans (Ansari et al., 2014).

Rats with MHRS showed a significant elevation in all liver fat with dyslipidemia which may be due to feeding high fructose as described by Kawasaki et al. (2009) and Al-Okbi et al. (2013). Nigella sativa oil showed previously to produce a hepatoprotective effect in rats (Al-Suhaimi, 2012) which was confirmed by the work of Al-Okbi et al. (2013), who reported its protective effect against steatohepatitis. This effect was ascribed to the volatile oil fraction, particularly thymoquinone and p-cymene and to a lesser extent to the fatty acid profile of Nigella crude oil. So, it was important to extend the study on the protective effect of Nigella sativa crude oil in rats in which MHRS was induced. The quantity and quality of the volatile oil fraction of Nigella sativa 
crude oil used in the present study differs from that used to evaluate the protective effect against steatohepatitis in our previous work (Al-Okbi et al. 2013). The crude oil in the current study contains a higher volatile oil fraction $(2.6 \mathrm{wt} \%)$ and different contents of the volatile constituents thymoquinone $(68.1 \%$, GC area) and p-cymene (20.1\%, GC area) than in the previous work in which these parameters were $0.1 \mathrm{wt} \%, 39.1 \%$, and $40.2 \%$, respectively.

Concerning the fatty acid composition of Nigella crude oil, the current study showed that the oil is rich in omega-6 (60.4\%) and omega-9 $(25.2 \%)$ but scarce in omega 3 - fatty acids $(0.2 \%)$. Therefore, due to the role of omega-3 fatty acids as hepatoprotective and anti-inflamatory agents (Raptis et al., 2014; Al-Okbi and Mohamed, 2012), it was decided in the present study to blend Nigella crude oil with other omega-3 fatty acid rich oils from marine as well as plant origins such as fish and flaxseed oils, respectively.

In the current study, treatment with Nigella crude oil or its binary blend with either fish or flaxseed oils produced a significant improvement in all biochemical parameters. This improvement only reaches the normal levels in the case of plasma creatinine and urea and even showed a more significant improvement than normal concerning plasma TNF- $\alpha$. All other biochemical parameters, although significantly improved, did not reach the level of the normal group. This means that the different treatments did not provide complete protection, but reduced the progression of HRS. There were no significant changes in the biochemical parameters among the different test groups (kept on different oil treatments). This result showed that blending half the dose of Nigella crude oil with either flaxseed oil or fish oil produced no further improvement in the biochemical parameters compared with Nigella crude oil alone. This means that increasing omega-3 fatty acids at the expense of crude oil constituents including fatty acids and volatile oils did not add to the hepato-protective effect of Nigella crude oil. It is well documented that decreasing the ratio of $n-6 / n-3$ fatty acids renders the oil antiinflammatory and beneficial health effect. Although the present oil blends showed lower n-6/n-3 fatty acids than Nigella crude oil, they did not afford extra beneficial effects towards MHRS. This may be explained on the basis of the presence of volatile oils in Nigella crude oil (present at 2.6\%) that possess antioxidant and anti-inflammatory activity. Some other constituents not determined in the present study could also be responsible for the biological activity of Nigella sativa crude oil; these are phytosterols and alpha and gamma- tocopherols (Cheikh-Rouhou et al., 2008; Ramadan et al., 2012) that possess antioxidant and anti-inflammatory effects. Although fish oil and flaxseed oil contain high percentages of omega-3 fatty acids, they lack the presence of antioxidants compared to Nigella crude oil.
Hyperbilirubinemia as shown in MHRS models in the present study might be detrimental to liver and renal functions. The systemic reduction in bilirubin concentration by the different oil treatments might contribute to the normalization of the urinary levels of prostaglandins and thromboxane B2, to decrease in serum bile acid levels, and to the improvement of the hepatic energy charge that may reflect improvement in both liver and kidney dysfunctions as reported by Kamisako et al. (1998).

It could be noticed from the present study that although polyunsaturated omega-3 fatty acids were higher in rats given the mixture of Nigella crude oil with either fish oil or flaxseed oil, MDA was not elevated and total antioxidant was not reduced, but improved. This could be due to the presence of antioxidant constituents supplemented from $N$. sativa crude oil. The results of studies examining the effects of increased proportions of polyunsaturated fatty acids in the diet on indexes of lipid peroxidation in vivo are contradictory (Wander et al., 1996; Harats et al., 1991; Meydani et al., 1991). With fish-oil supplementation, there was no evidence of increased lipid peroxidation when assessed by plasma F2-isoprostanes and MDA (Higdon et al., 2000), which agreed with the present study.

Diets relatively high in unsaturated fat have favorable effects on lipoprotein-cholesterol profiles (Mensink and Katan, 1992; Mattson and Grundy, 1985) which agreed with the present results. It was also shown previously that chronic supplementation of fish oil demonstrated a reno-protective effect (Fernandez et al., 2004) which confirms the present results.

Flaxseeds is a leading source of $\alpha$-linolenic acid (ALA) which account for $57.9 \%$ of total fatty acids. In the present study, this amount was higher than that reported previously $(52 \%)$ by Oomah and Mazza (1995). Mohamed et al. (2005) showed that flaxseed produced a reduction in plasma $\mathrm{T}$-ch and LDL-ch in hyper-cholesterolemic rats. The same effect was reported for the consumption of flaxseed in humans (Clark et al., 1995; Jenkins et al., 1999). ALA, which is an omega-3-fatty acid, has been reported to be useful in the prevention and treatment of coronary artery disease and hypertension (Simopoulos, 1999). This is because ALA is the precursor for the synthesis of eicosapentaenoic (EPA) and docosahexaenoic acids (DHA) which are associated with the control of cardiovascular diseases (Bibus et al., 1998). ALA also reduces serum triglycerides and the development of thrombosis and arteriosclerosis (Pszczola, 1998). Also, flaxseed was shown to have an impact on the treatment of lupus nephritis (Clark et al., 1995) in humans and improvement of renal dysfunction during cisplatin treatment in rats (Al-Okbi et al., 2014), pointing to its reno-protective effect. Flaxseed oil attenuated the decline in renal function and reduced glomerular 
injury (Caligiuri et al., 2013). It has also been shown that treatment with flaxseed oil caused a significant improvement in the histopathological picture of the kidney as well as the kidney function and antioxidant status, against lead acetate-induced renal toxicity (Abdel-Moneima et al., 2011). It was reported that rats fed a flaxseed-supplemented diet had significantly lower blood pressure and a significantly improved lipid profile, liver and kidney functions in the hypertensive condition. These effects are likely to be mediated by the ALA and linoleic acid contents of flaxseed oil (Al-Bishri, 2013).

The treatment of MHRS rats with mixtures of oils containing omega- 3 fatty acids produced an improvement in renal function in the present study. Over the past 25 years, several studies have suggested the efficacy and potential clinical utility of dietary supplementation with omega-3 fatty acids in human renal diseases (Donadio, 2001; De Caterina et al., 1994; Baggio et al., 2002; Azar et al., 1989).

It is accepted that the effect of omega-3 fatty acids on kidney diseases related to the activities of metabolites derived from EPA opposed those derived from arachidonic acid (AA). Alterations in eicosanoid synthesis and metabolism are produced when concentrations of EPA and DHA increase in relation to AA. For example, the renal production of thromboxane A2 is elevated in several renal diseases and treatment with n-3 fatty acids reduced it (Fernandez et al., 2004).

The non significant changes in different nutritional parameters in the present study are similar to the results reported by Kawasaki et al. (2009) and Al-Okbi et al. (2013) when rats fed similar high fructose diets without a glucosamine injection were compared with balanced diets. The significant reduction in final body weight, body weight gain and food efficiency ratio on administration of Nigella crude oil agreed with previous results (Al-Okbi et al., 1997; Houcher et al., 2007).

\section{CONCLUSION}

MHRS induced in rats through feeding a high fructose diet followed by an intraperitoneal injection of galactosamine hydrochloride produced liver and kidney dysfunction. The same model showed reduced hemoglobin, elevated oxidative stress, increased inflammatory biomarker, elevated ET-1, elevated plasma cholesterol, reduced plasma HDL-Ch, reduced plasma albumin, reduced plasma $\mathrm{Ca}$ and elevated urinary NAG and liver fats. These changes confirm the induction of HRS. The administration of Nigella crude oil or its blend with fish or flaxseed oils significantly improved all biochemical parameters of MHRS but without complete protection. Changing the fatty acid profile of Nigella crude oil by blending with those omega-3 fatty acid-rich oils did not make any difference in the therapeutic efficiency of Nigella crude oil alone. That can reflect the superiority of this oil and potentially its volatile oil fraction as hepatoprotective agents.

\section{REFERENCES}

Abdel-Moneima E, Dkhila A, Al-Quraishy S. 2011. The protective effect of flaxseed oil on lead acetate-induced renal toxicity in rats. J. Hazard. Mater. 194, 250-255. http://dx.doi. org/10.1016/j.jhazmat.2011.07.097.

Al-Bishri M. 2013. Favorable effects of flaxseed supplemented diet on liver and kidney functions in hypertensive Wistar rats. J. Oleo Sci. 62, 709-715. http://dx.doi.org/10.5650/ jos.62.709.

Al-Okbi S, Ammar N, Abd El-Kader M. 1997. Studies of some biochemical, nutritional and anti-inflammatory effects of Nigella Sativa seeds. Egypt. J. Pharmaceut. Sci. 38, 451-469.

Al-Okbi S, Mohamed D. 2012. Preparation and Evaluation of functional foods in adjuvant arthritis. Grasas Aceites. 63, 394-402. http://dx.doi.org/10.3989/gya.130811

Al-Okbi S, Mohamed D, Hamed Th, Edris A. 2013. Potential protective effect of Nigella sativa crude oils towards fatty liver in rats. Eur. J. Lipid Sci. Technol. 115, 774-782. http:// dx.doi.org/10.1002/ejlt.201200256.

Al-Okbi S, Mohamed D, Hamed Th, Esmail S, Donya M. 2014. Prevention of renal dysfunction by nutraceuticals prepared from oil rich plant foods. Asian Pacific J. Trop. Biomed. 4, 618-627. http://dx.doi.org/10.12980/APJTB.4.201414B66.

Al-Suhaimi A. 2012. Hepatoprotective and immunological functions of Nigella sativa seed oil against hypervitaminosis A in adult male rats. Inter. J. Vitamin and Nutr. Res. 82, 288-297. http://dx.doi.org/10.1024/0300-9831/a000121.

Anand R, Harry D, Holt S, Milner P, Dashwood M, Goodier D, Jarmulowicz M, Moore K. 2002. Endothelin is an important determinant of renal function in a rat model of acute liver and renal failure. Gut. 50, 111-117. http://dx.doi. org/10.1136/gut.50.1.111.

Ansari I, Sheikh A, Ahmed S, Jabbar Q, Ali S. 2014. Management of anemia and other hematologic derangements in patients with chronic kidney disease. Arab J. Nephrol. Transplant. 7, 13-19.

Arroyo V, Ginès P, Gerbes A, Dudley J, Gentilini P, Laffi G, Reynolds B, Ring-Larsen H, Schölmerich J. 1996. Definition and diagnostic criteria of refractory ascites and hepatorenal syndrome in cirrhosis. Hepatol. 23, 164-176. http://dx.doi. org/10.1002/hep.510230122.

Aydogdu S, Akil I, Akil T, Akil T, Kabasakal C, Killi R, Mir S, Yağci R. 2004. Renal resistive indexes and some renal functions in liver cirrhotic children. Pediatr. Int. 46, 67-71.

Azar R, Dequiedt F, Awada J, Dequiedt P, Tacquet A. 1989. Effects of fish oil rich in polyunsaturated fatty acids on hyperlipidemia of hemodialysis patients. Kidney Int. 27, S239-S242.

Baggio B, Budakovic A, Priante G, Gambaro G, Manzato E, Khan S. 2002. Dietary fatty acid supplementation modulates the urinary excretion of calcium and oxalate in the rat. Insight into calcium lithogenesis. Nephron. 91, 486-491. http://dx.doi.org/10.1159/000064292.

Bataller R, Sort P, Gine's P, Arroyo V. 1998. Hepatorenal syndrome: definition, pathophysiology, clinical features and management. Kidney Int. Suppl. 66, S47-S53.

Bibus M, Stitt P. Holman T. 1998. Ratios of linoleic to a-linolenic acids in the diet: Implications in the health of humans and companion animals, in Proceedings of the $57^{\text {th }}$ Flax Institute of the U.S., Fargo, ND, pp. 49-52.

Briggs M, Williams A. 1963. A new mineral mixture for experimental rat diets and evaluation of other mineral mixtures. Feder. Proceedings. 22, 261-266.

Burstein M, Scholnick H, Morfin R. 1970. Rapid method for the isolation of lipoproteins from human serum by precipitation with polyanions. J. Lipid Res. 11, 583-595.

Caligiuri P, Love K, Winter T, Gauthier J, Taylor G, BlydtHansen T, Zahradka P, Aukema M. 2013. Dietary linoleic acid and $\alpha$-linolenic acid differentially affect renal oxylipins and phospholipid fatty acids in diet-induced obese rats. 
J. Nutrit. 143, 1421-1431. http://dx.doi.org/10.3945/jn. 113.177360

Cequier-Sánchez E, Rodríguez C, Ravelo G, Zárate R. 2008. Dichloromethane as a solvent for lipid extraction and assessment of lipid classes and fatty acids from samples of different natures. J. Agric. Food Chem. 56, 4297-4303. http://dx.doi.org/10.1021/jf073471e.

Cheikh-Rouhou S, Besbes S, Lognay G, Blecker C, Deroanne C, Attia H. 2008. Sterol composition of black cumin (Nigellas ativa L.) and Aleppo pine (Pinus halepensis Mill.) seed oils. J. Food Comp. Anal. 21, 162-168. http://dx.doi.org/10.1016/j. jfca.2007.09.001.

Clark F, Parbtani A, Huff W, Spanner E, de Salis H, Chin-Yee I, Philbrick J, Holub J. 1995. Flaxseed: a potential treatment for lupus nephritis. Kidney Int. 48, 475-483. http://dx.doi. org/10.1038/ki.1995.316.

Davenport A, Ahmad J, Khafaji A, Kellum J, Genyk S, Nadim K. 2012. Medical management of hepatorenal syndrome. Nephrol. Dial Transpl. 27, 34 41. http://dx.doi.org/10.1093/ ndt/gfr736.

De Caterina R, Endres S, Kristesen S, Schmidt E. 1994. n-3 Fatty acids and renal diseases. Amer. J. Kidney Dis. 24, 397-415. http://dx.doi.org/10.1016/S0272-6386(12)80896-1.

Demirbas T, Piskin T, Dayangac M, Yaprak O, Oklu L, Yuzer Y, Tokat Y. 2012. Successful treatment of severe hepatorenal syndrome with living donor liver transplantation. Hepatogastroenterol. 59, 2305-2306.

Donadio V. 2001. n-3 Fatty acids and their role in nephrologic practice. Current Opin. Nephrol. Hyperten. 10, 639-642.

Doumas T, Watson A, Biggs G. 1972. Albumin standards and the measurement of serum albumin with bromocresol green. Clin. Chem. Acta. 31, 87-96. http://dx.doi.org/10.1016/ 0009-8981(71)90365-2.

European Pharmacopoeia 1996. Conseil del'Europe: Pharmacopée Européenne. France: Maisonneuve S.A., Sainte Ruffine

Fagundes C, Ginè P. 2012. Hepatorenal syndrome: A severe, but treatable, cause of kidney failure in cirrhosis. Am. J. Kidney Dis. 59, 874 885. http://dx.doi.org/10.1053/j.ajkd.2011.12.032.

Fawcett K, Scott E. 1960. A rapid and precise method for the determination of urea. J. Clin. Pathol. 13, 156-159. http:// dx.doi.org/10.1136/jcp.13.2.156.

Fernandez R, Piechnik J, Fabris R, Malnic G, Fernandes L. 2004. Effect of chronic fish oil supplementation on renal function of normal and cachectic rats. Brazil. J. Med. Biolog. Res.37, 1481-1489.http://dx.doi.org/10.1590/S0100879X2004001000006.

Folch J, Lees M, Sloane-Stanley H. 1957. A simple method for the isolation and purification of total lipides from animal tissues. J. Biol. Chem. 226, 497-509.

Gambino R. 1965. Standard Methods of Clinical Chemistry. Academic Press, New York.

Garcia-Martinez R, Caraceni P, Bernardi M, Gines P, Arroyo V, Jalan R. 2013. Albumin: Pathophysiologic basis of its role in the treatment of cirrhosis and its complications. Hepatol. 58, 1836-1846. http://dx.doi.org/10.1002/hep.26338.

Harats D, Dabach Y, Hollander G, Ben-Naim M, Schwartz R, Berry EM, Stein O, Stein Y. 1991. Fish oil ingestion in smokers and nonsmokers enhances peroxidation of plasma lipoproteins. Atheroscler. 90, 127-139. http://dx.doi.org/ 10.1016/0021-9150(91)90107-E.

Higdon V, Liu J, Du H, Morrow D, Ames N, Wander C. 2000. Supplementation of postmenopausal women with fish oil rich in eicosapentaenoic acid and docosahexaenoic acid is not associated with greater in vivo lipid peroxidation compared with oils rich in oleate and linoleate as assessed by plasma malondialdehyde and F2-isoprostanes1-3. Am. J. Clin. Nutr. 72, 714-722.

Houcher Z, Boudiaf K, Benboubetra M, Houcher B. 2007. Effects of methanolic extract and commercial oil of Nigella sativa L. on blood glucose and antioxidant capacity in alloxan-induced diabetic Rats. Pteridines. 18, 8-18. http://dx.doi.org/10.1515/pteridines.2007.18.1.8.

Houot O. 1985. Interpretation of Clinical Laboratory Tests. Biomedical Publications. (Doi not available).

Jenkins G, Kendall W, Vidgen E, Agarwal S, Rao V, Rosenberg S, Diamandis P, Novokmet R, Mehling C, Perera T, Griffin C,
Cunnane C. 1999. Health aspects of partially defatted flaxseed, including effects on serum lipids, oxidative measure and ex vivo androgen and progestin activity: a controlled cross-ovar trial. Am. J. Clin. Nutr. 69, 395-403.

Kamisako T, Miyawaki S, Gabazza C, Ishihara T, Kamei A, Kawamura N, Adachi Y. 1998. Polyethylene glycol-modified bilirubin oxidase improves hepatic energy charge and urinary prostaglandin levels in rats with obstructive jaundice. J. Hepatol. 29, 424 429. http://dx.doi.org/10.1016/S01688278(98)80060-3

Kawasaki T, Igarashi K, Koeda T, Sugimoto K, Nakagawa K, Hayashi S, Yamaji R, Inui H, Fukusato T, Yamanouchi T. 2009. Rats fed fructose-enriched diets have characteristics of nonalcoholic hepatic Steatosis. J. Nutr. 139, 2067-2071. http://dx.doi.org/10.3945/jn.109.105858.

Koracevic D, Koracevic G, Djordjevic V, Anderejevic S, Cosic V. 2001. Methods for the measurement of antioxidant activity in human fluids. J. Clin. Pathol. 54, 356-361. http:// dx.doi.org/10.1136/jcp.54.5.356.

Mattson H, Grundy M. 1985. Comparison of effects of dietary saturated, monounsaturated, and polyunsaturated fatty acids on plasma lipids and lipoproteins in man. J. Lipid Res. 26, 194-202.

Megraw R, Dunn D, Biggs H. 1979. Manual and continuous flow colorimetry of triglycerols by a fully enzymatic method. Clin. Chem. 25, 273-284.

Mensink P, Katan B. 1992. Effect of dietary fatty acids on serum lipids and lipoproteins. A meta-analysis of 27 trials. Arterioscler. Thrombo. Vascular Biol. 12, 911-919. http:// dx.doi.org/10.1161/01.ATV.12.8.911.

Meydani M, Natiello F, Goldin B, Free N, Woods M, Schaefer E, Blumberg B, Gorbach L. 1991. Effect of long-term fish oil supplementation on vitamin E status and lipid peroxidation in women. J. Nutr. 121, 484-91.

Mohamed A, El-Hariri M, Al-Okbi Y. 2005. Impact of feeding bread enriched with flaxseed on plasma profile of hyperlipidemic rats. Polish J. Food Nutr. Sci. 14 (4), 431- 436. (Doi not available).

Mohindra S, Kumar K. 2013. Hepatorenal syndrome clinical queries. Nephrol. 2, 205-211.

Morcos R. 1967. The effect of protein value of the diet on the neurological manifestations produced in rats by B-immodipropionitrile. British J. Nutr. 21, 269-274. http:// dx.doi.org/10.1079/BJN19670029.

Muñoz S. 2008. The hepatorenal syndrome. Medical Clin. 92 (4), 813-837. http://dx.doi.org/10.1016/j.mcna.2008.03.007.

Oomah D, Mazza G. 1995. Flaxseed dietary fiber and cyanogens, in Cunnane, S., Thompson, L (Ed.) Flaxseed in Human Nnutrition. Champaign, AOCS Press Illinois, USA, pp. 56-67.

Planas R, Montoliu S, Balleste B, Rivera M. Miquel M, Masnou H, Galeras A, Giménez D, Santos J, Cirera I, Morillas M, Coll S, Solà R. 2006. Natural history of patients hospitalized for management of cirrhotic ascites. Clin. Gastroenterol. Hepatol. 4, 1385-1394. http://dx.doi.org/10.1016/j.cgh.2006. 08.007 .

Price G, Whiting H. 1992. Urinary enzymes and nephrotoxicity in humans, in Jung K, Mattenheimer H, Burchardt U (Ed.) Urinary Enzymes Springer-Verlag, Berlin, pp. 203-221. http://dx.doi.org/10.1007/978-3-642-84313-6_14.

Pszczola E. 1998. The ABCs of nutritional ingredients. Food Technol. 52, 30-38.

Ramadan F, Wahdan K. 2012. Blending of corn oil with black cumin (Nigella sativa) and coriander (Coriandrum sativum) seed oils: Impact on functionality, stability and radical scavenging activity. Food Chem. 132, 873-879. http:// dx.doi.org/10.1016/j.foodchem.2011.11.054.

Raptis D, Limani P, Jang J, Ungethüm U, Tschuor C, Graf R, Humar B, Clavien A. 2014. GPR 120 on Kupffer cells mediates hepatoprotective effects of $\omega 3$-fatty acids. J. Hepatol. 60, 625-632. http://dx.doi.org/10.1016/j.jhep.2013.11.006

Reitman S, Frankel S. 1957. Colorimetric methods for aspartate and alanine aminotransferase. Am. J. Clin. Pathol. 28, 55-60.

Saracyn M, Patera J, Kocik J, Brytan M, Zdanowski R, Lubas A, Kozłowski W, Wańkowicz Z. 2012. Strain of experimental animals and modulation of nitric oxide pathway: their 
influence on development of renal failure in an experimental model of hepatorenal syndrome. Arch. Medical Sci. 8, 555-562. http://dx.doi.org/10.5114/aoms.2012.29281.

Saracyn M, Wesołowski P, Nowak Z, Patera J, Kozłowski W, Wańkowicz Z. 2008. Race of experimental animals and development of renal failure in animal model of hepatorenal syndrome. Polish Merkur Lekarski. 24, 298-302.

Satoh K. 1978. Serum lipid peroxide in cerebrovascular disorders determined by a new colorimetric method. Clinica Chimica Acta. 20, 37-43.

Schriewer H, Kohnert U, Assmann G. 1984. Determination of LDL cholesterol and LDL apolipoprotein B following precipitation of VLDL in blood serum with phosphotungstic acid/ $\mathrm{MgCl}_{2}$. J. Clin. Chem. Clin. Biochem. 22, 35-40. http:// dx.doi.org/10.1515/cclm.1984.22.1.35.

Shah N, Mohamed E, Jover-Cobos M, Macnaughtan J, Davies N, Moreau R, Paradis V, Moore K, Mookerjee R, Jalan R. 2013. Increased renal expression and urinary excretion of TLR4 in acute kidney injury associated with cirrhosis. Liver Internation. 33, 398-409. http://dx.doi.org/10.1111/ liv.12047.

Simopoulos P. 1999. Essential fatty acids in health and chronic disease. Am. J. Clin. Nutr. 70, 560S-568S.

Skálová S. 2005. The diagnostic role of urinary N-acetyl-betaD-glucosaminidase (NAG) activity in the detection of renal tubular impairment. Acta Medica (Hradec Kralove). 48, 75-80.

Snowdon V, Pellicoro A, Ramachandran P, Mungall W, Jansen M, Lennen R, Aucott R, Kendall T, Hughes J, Iredale J, Fallowfield J. 2013. Relaxin is a renal vasodilator in experimental models of cirrhosis and a potential novel therapy for hepatorenal syndrome in man. The Lancet. 381, S102 (special issue). http://dx.doi.org/10.1016/S0140-6736(13)60542-5.

Stepaniak A, Gould E, Sun D, Swanborg H. 1995. A comparative study of experimental autoimmune encephalomyelitis in Lewis and DA rats. J. Immunol. 155, 2762-2769.

Üstun G, Kent L, Cekin N, Civelekoglu, H. 1990 Investigation of the technological properties of Nigella sativa (black cumin) seed oil. J. Am. Oil Chem. Soc. 67 (12), 958-960. http://dx.doi.org/10.1007/BF02541857.

Van Lente F, Sult P. 1989. Assessment of renal function by serum creatinine and creatinine clearance: Glomerular filteration rate estimated by four procedures. Clin. Chem. 35 (12), 2326-2330.

VanKampen J, Zijlstra G. 1965. Determination of hemoglobin and its derivatives. Advces Clin. Chem. 8, 141-187.

Wadei H, Mai M, Ahsan N, Gonwa T. 2006. Hepatorenal syndrome: pathophysiology and management. Clin. J. Am. Soc. Nephrol. 1, 1066-1079. http://dx.doi.org/10.2215/CJN. 01340406.

Wander C, Du H, Ketchum O, Rowe E. 1996. Tocopherol influences in vivo indices of lipid peroxidation in postmenopausal women given fish oil. J. Nutr. 126, 643-652.

Watson D. 1960. A simple method for the determination of serum cholesterol. Clin. Chem. Acta. 5, 637-642. http:// dx.doi.org/10.1016/0009-8981(60)90004-8.

Zhou Z, Davar G, Strichartz G. 2002. Endothelin-1 (ET-1) selectively enhances the activation gating of slowly inactivating tetrodotoxin-resistant sodium currents in rat sensory neurons: A mechanism for the pain-inducing actions of ET-1. J. Neurosci. 22 (15), 6325-6330. 